\title{
The patient with reactive airways disease
}

$\mathrm{T}$ HE term "reactive airways disease" is considered to be synonymous with asthma. However, airway reactivity is also increased in allergic rhinitis, bronchitis, emphysema, and respiratory viral infections. The airways of such patients have exaggerated constrictive responses to different physical, chemical, and environmental stimuli. While the asthmatic patients have chronic hyper-reactivity of the airways, patients with upper respiratory tract infection (URI) have acute airway reactivity which may last up to six weeks following the recovery from the initial viral infection. ${ }^{1}$ These patients often engender anxiety among even the most experienced anaesthetists because of the possibility of severe bronchospasm in the perioperative period. Indeed, the ASA Closed Claims Study reported that $2 \%$ of all respiratory claims were related to bronchospasm and $70 \%$ of these claims were for subsequent death. ${ }^{2}$ Therefore, it is important to understand the epidemiology, aetiology, pathogenesis, and treatment of the reactive airway diseases.

\section{Asthma}

Despite continued advances in medicine asthma remains a problem that affects $5 \%$ of the adult and $10 \%$ of the paediatric population of developed countries. ${ }^{3}$ The prevalence and mortality associated with asthma have been steadily increasing in the United States and other parts of the world. In about $66 \%$ of the patients symptoms develop before five years of age, and the male outnumber female patients by about 2:1. A Center for Disease Controls (CDC) analysis of asthma-related clinical data from 1982 through 1991 revealed a $40 \%$ increase in the annual death rate. This increase was $59 \%$ for females and $34 \%$ for males. ${ }^{4}$ In Canada, 87,400 asthmatic patients are admitted to hospitals, and 400 to 500 of these die from the disease each year. ${ }^{5}$

\section{Pathophysiology of asthma}

Theories of the pathophysiology of asthma in the past have mainly focused on the bronchial smooth muscle and the reversible obstruction of air flow produced by bronchoconstriction. While these factors are important, current opinion considers airway inflammation to be of paramount importance in the pathogenesis of asthma. Unique features of the inflammation include prominence of eosinophils, a small increase in neutrophils, and early fibrosis. ${ }^{6}$ Atopy is seen in two thirds of the patients, but its presence is not essential for the manifestation of the disease. Clinically, a dichotomy of extrinsic vs intrinsic asthma is not very helpful. In all patients with asthma, there is an interplay among inflammatory cells, cytokines, chemical mediators, smooth muscle, neurogenic pathways, bronchial epithelium, vasculature, and increased secretions.

\section{Airway smooth muscle tone}

Airway narrowing in asthma results from the combined effects of inflammation, oedema and contraction of smooth muscle. Bronchoconstriction results from stimulation of receptors on the cell membranes of the smooth muscle by histamine, acetylcholine, and other allergens. Receptor stimulation causes activation of phosphoinositide hydrolysis, leading to the release of intracellular calcium ions, which cause smooth muscle contraction. Hydrolysis of membrane phosphoinositides is essential for intracellular calcium release following activation of surface receptors. When intracellular calcium increases, it binds with calmodulin to activate Myosin Light Chain Kinase (MLCK) which phosphorylates light chain myosin. The excitation contraction coupling of airway smooth muscle is dependent upon the concentration of free calcium ions in the myoplasm of the cells. ${ }^{7}$ The increase in muscle tension is determined by the magnitude of MLCK phosphorylation.

\section{Inflammatory cells and mediators}

It is well established that inflammatory cells, mediators, and cytokines play an important role in the pathogenesis of asthma. At the cellular and molecular level, the disease may be divided into immediate and delayed responses. The early response is mast cell mediated whereas the delayed response involves eosinophils, lymphocytes, neutrophils, and alveolar macrophages. In the early response, antigenic stimulation of the mast cell $\mathrm{IgE}$ receptors results in the liberation of mediators such as histamine, tryptase, heparin, and chemotactic factors. 
Also, phospholipid membrane derived mediators prostaglandin D2, leukotriene B4, and cysteinyleleukotrienes are liberated, and produce severe bronchoconstriction within minutes. In the delayed response, the onset occurs 6 to 12 hours following antigenic challenge. Eosinophil and lymphocyte activation is stimulated by leukotrienes, platelet activating factor, interleukins IL2 and IL5, and granulocyte-macrophage colony stimulating factor (GM-CSF). Increased levels of messenger RNA for the cytokines IL2, IL3, IL4, IL5, and GM CSF have been found in asthmatic patients. ${ }^{8}$ All these mediators contribute towards bronchoconstriction, increased vascular permeability, mucus secretion, and cellular chemotaxis.

\section{Mechanism of airway byperactivity}

A variety of stimuli can trigger alteration of bronchomotor tone. Exercise, pollutants, irritants, allergens, motion and cold air may all precipitate bronchospasm. Normally a tonic constriction exists in all human airways and this is under vagal parasympathetic control. The resting bronchomotor tone provides a balance between the anatomical dead space and airway resistance. ${ }^{9}$ Asthmatic patients have hypertrophy and hyperplasia of airway smooth muscle with enhanced airway reactivity. ${ }^{10}$ Hyperactivity of the airways also occurs in viral infections that can severely damage the epithelial barrier and expose the subepithelial receptors to noxious stimuli. ${ }^{11,12}$ The loss of epithelium may also result in decreased production of epithelium derived relaxation factors (EDRF) and neuropeptidases which destroy constrictor elements. ${ }^{13}$

\section{Autonomic nervous system and bronchomotor tone}

Increased parasympathetic or decreased sympathetic activity is responsible for enhanced airway tone and reactivity. ${ }^{14}$ The parasympathetic nervous system mainly influences the bronchomotor tone, and direct sympathetic supply to the lungs is rather limited. The sympathetic influence on bronchomotor tone is mediated by the circulating catecholamines which act on the $B_{2}$ receptors and produce bronchodilatation by increasing cyclic AMP in smooth muscle. Different sensory receptors alter bronchomotor tone via afferent parasympathetic pathways. Located deep within the smooth muscle of the posterior tracheal wall are the slowly adapting stretch receptors which regulate the rate and depth of breathing, and are also responsible for the Hering-Breuer inflation reflex. ${ }^{15}$ The rapidly adapting irritant receptors are present in the mucosa of the airways and respond to mechanical, thermal, and irritant particulate or gaseous stimuli. The juxtapulmonary, or "J" receptors, are located between the alveoli adjacent to pulmonary capillaries and respond to changes from pulmonary congestion, edema, inflammation, and exercise. The efferent parasympathetic pathways travel down the vagus nerve to form synapses in ganglia within the airway walls. The postsynaptic membranes of these ganglia termed nicotinic cholinergic receptors, are activated by acetylcholine. This activation is modulated by muscarinic receptors $(\mathrm{M})$, which are present in the same autonomic ganglia. The short post ganglionic fibres pass to the airway smooth muscle and submucosal glands. Stimulation of the postjunctional muscarinic $\mathrm{M}_{3}$ receptors by acetylcholine results in smooth muscle contraction. The prejunctional $\mathrm{M}_{2}$ muscarinic receptors are inhibitory in nature and limit the degree of cholinergic bronchoconstriction by providing a negative feedback for acetylcholine release. ${ }^{16}$

\section{Cholinergic co-transmission}

In addition, another "non-adrenergic - non-cholinergic" neural pathway (NANC) has been described. ${ }^{17}$ This neural network affects the entire trachea and the smallest of the bronchi. It consists of an inhibitory system that produces bronchodilatation, and an excitatory component that causes bronchoconstriction. The precise role of these pathways remain to be defined with clarity.

\section{Classification of asthma}

Asthma is not a single disease but is comprised of a group of disorders with various pathologic mechanisms. Principal classifications of bronchial asthma include:

1. Atopic, or immunoglobulin E mediated asthma,

2. Exercised-induced asthma,

3. Occupational asthma,

4. Infectious asthma, and

5. Aspirin-induced asthma.

Immunoglobulin $\mathrm{E}$ mediated bronchial asthma is the most common form and is believed to be an inherited condition. Following inhalation of antigenic substances, IgE antibodies are formed. Upon re-exposure to these inhaled antigens, an antigen-antibody complex is formed on the surface receptors of mast cells. The resulting conformational change of the cell membrane leads to the liberation of vasoactive mediators including histamine which cause constriction of the bronchial smooth muscle.

Irrespective of the classification, in all types of asthma the same vasoactive mediators are released resulting in similar bronchoconstriction and air flow obstruction. 


\section{Preoperative assessment}

A history of episodic bouts of dyspnea and wheeze should alert one to the presence of a bronchospastic disease. To avoid the occurrence of bronchospasm in the perioperative period a detailed preoperative history and evaluation is necessary (Table I).

The symptoms of nocturnal dyspnea and tightness of the chest on awakening are highly predictive of bronchial reactivity. ${ }^{18}$ Patients with symptoms, and those with a history of smoking, should be investigated for the presence of airway constriction, its severity

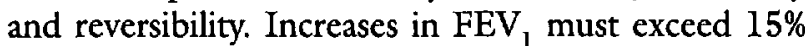
for the change to be considered as being significantly reversible following bronchodilator therapy. Peak expiratory flow rate (PEFR) can be measured easily and is a fairly reproducible test of airway obstruction. Small diurnal variations in PEFR occur in healthy individuals; however, these changes are exaggerated in patients with asthma ${ }^{19}$ and allergic rhinitis. ${ }^{20}$ While cough and dyspnea may suggest airway disease, bronchial provocation testing with methacholine may be used to identify airway hyper-responsiveness.

On the basis of history and clinical findings, Kingston and Hirschman ${ }^{21}$ have proposed classifying the asthmatic patient into one of the three groups (Table II). This clinical classification takes into account the severity of illness

TABLE I Points to be elicited in Preoperative Evaluation of Asthmatic Patients

\begin{tabular}{ll}
\hline Aspect of History & Characterization \\
\hline Patient & Age at onset of asthma \\
& Allergies \\
& Psychological or social factors \\
Disease & Cyclic patterns \\
& Precipitating factors \\
& Interference with sleep \\
& Manifestations: cough, sputum \\
& (colour \& quantity) \\
Medical Treatment & Medication \\
& Number of hospitalizations \\
& Previous anaesthetics \\
\hline
\end{tabular}

TAB LE III Clinical Classification of Impairment of Pulmonary Function in Asthma (\% of normal)

\begin{tabular}{lcc}
\hline & $V C, F V C, F E V_{1}, M V V$ & FEF 25-75\% \\
\hline Normal & $>80 \%$ & $>75 \%$ \\
Mild & $65-80 \%$ & $60-75 \%$ \\
Moderate & $50-64 \%$ & $45-59 \%$ \\
Severe & $35-49 \%$ & $30-44 \%$ \\
Very severe & $<35 \%$ & $<30 \%$ \\
\hline
\end{tabular}

and is considered useful in predicting the probability of complications and the resulting morbidity in the perioperative period. After pulmonary function testing, one may further identify the severity of the disease (Table III). In addition to pulmonary function testing, the following laboratory investigations may also be considered.

\section{Arterial blood gas analysis}

This is rarely indicated as a routine in the preoperative evaluation of an asthmatic patient. Hypercarbia and hypoxaemia is indicative of severe disease.

\section{Chest $x$-ray}

Routine chest films are usually of little value and are only useful to rule out complicating factors such as pneumonia or heart failure.

\section{Electrocardiogram}

Asthmatic patients may show right bundle branch block, ventricular ectopy, or an acute increase in right atrial size during an attack. Since hypoxia during an attack may contribute towards serious cardiac abnormalities, a base line ECG can be useful.

\section{Anaesthetic approach}

Regional anaesthesia has much to offer in an asthmatic patient, and remains the anaesthetic technique of choice. When this is not feasible and general anaesthesia is deemed necessary, one should avoid using drugs likely to trigger histamine release and other vasoactive substance liberation. Also, where possible tracheal intubation should be avoided.

TABLE II

\begin{tabular}{cll}
\hline Group & History & Desired Intervention \\
\hline I & History of wheezing & Routine physical examination \\
& Has not experienced wheezing for years & Preoperative spirometry desirable \\
& Does not take medication for asthma & \\
II & No active wheezing & Preoperarive spiromety necessary \\
& History of recurrent bronchospasm & Blood gas analysis desirable \\
& Currently on bronchodilator therapy & Prophylactic bronchodilators recommended \\
III & Active wheezing preoperatively & Preoperative spirometry necessary \\
& Currently on bronchodilator therapy & Blood gas analysis necessary \\
& Intensive bronchodilator therapy required & \\
\hline
\end{tabular}




\section{Premedication}

Opioids should be avoided since they may cause histamine liberation and respiratory depression. The $\mathrm{H}_{1}$ receptor antagonists with sedative and drying properties are useful adjuncts, while $\mathrm{H}_{2}$ receptor antagonists alone may be deleterious because of inhibition of the inhibitory feedback control of mediator release. Benzodiazepines are an excellent choice.

\section{Induction agents}

While thiopentone, in clinical doses, does not reliably protect against reflexly induced bronchospasm, it is not contraindicated in the asthmatic patient. It appears that the presence of the endotracheal tube during light anaesthesia and not thiopentone per se is associated with a higher incidence of bronchospasm. ${ }^{22}$ At clinical concentrations, thiopentone caused a dosedependent constriction, but at slightly higher concentrations it was shown to cause a bronchodilatation. ${ }^{23}$ Ketamine induction produces smooth muscle relaxation both directly and by releasing catecholamines thereby producing a salutary effect on the bronchomotor tone in an asthmatic patient. Etomidate neither liberates histamine nor initiates bronchospasm. Likewise, propofol has been shown to be a safe drug for induction in asthmatic patients, and has a significantly lower incidence of bronchospasm compared to induction with thiopentone.

\section{Inbalational agents}

Halothane, enflurane and isoflurane are effective in preventing and reversing bronchoconstriction. ${ }^{24}$ Likewise, sevoflurane has a salutary effect in asthmatic patients. In contrast, desflurane may cause bronchoconstriction due to its pungency and irritation of the trachea In the presence of toxic serum aminophylline concentrations, there is a greater tendency for ventricular dysrhythmias with halothane than with enflurane, isoflurane, sevoflurane, or desflurane. Morphine use is associated with increased plasma histamine concentrations and should be avoided.

\section{Neuromuscular blocking agents}

Drugs such as d-tubocurarine and atracurium liberate histamine and should be avoided. Reversal with neostigmine may precipitate bronchospasm through stimulation of muscarinic receptors and this can be prevented by appropriate administration of atropine. Pancuronium, vecuronium, and rocuronium do not liberate histamine and therefore can be used safely in asthmatic patients.

\section{Local anaesthetics}

Administration of $1.5 \mathrm{mg} \cdot \mathrm{kg}^{-1}$ lidocaine prevents reflexinduced bronchospasm and its use is recommended before airway manipulation, both at the time of intubation and extubation. There are no advantages to using procaine or bupivacaine compared with lidocaine.

\section{Specific medication therapy in asthma}

There are two major groups of drugs currently available to combat bronchospasm in asthmatic patients; bronchodilators to reverse or prevent bronchospasm, and anti-inflammatory drugs to control an unwanted inflammatory response. The route of administration as an aerosol is particularly advantageous since it delivers the drug at the site of action in the tracheobronchial tree. ${ }^{25}$ The major drugs (which include xanthines, sympathomimetics, and steroids) represent the primary agents in the management of bronchospasm and are useful in the preoperative management of asthma. The minor compounds (mucolytics, histamine receptor blockers, mast cell stabilizers, parasympatholytic agents, and calcium blockers) are useful in the prophylaxis of asthma, but have limited value during acute bronchospasm.

\section{Anti-inflammatory drugs}

1. GLUCOCORTICOIDS

Glucocorticoids (GCS) are the most effective antiinflammatory drugs at present to alleviate symptomatic bronchoconstriction. Inhalational therapy with beclomethasone dipropionate (BPD), in doses as small as $400 \mu \mathrm{g}$ are exceedingly effective. Beclomethasone diproprionate and its metabolite beclomethasone monopropionate are potent GCS with high affinity for pulmonary receptors. Glucocorticosteroid efficiency results from inhibition of formation and release of PAF, LTD4, LTB4, histamine and $\mathrm{PGE}_{2}$, and the production of cytokines; e.g., IL-1, IL-2, IL-6, TNF, and GM CSF. ${ }^{26}$ This inhibition is at the level of gene transcription and translation. The GCS-receptor complex binds to DNA, triggers mRNA transcription and induces synthesis of lipocortin and vasocortin which are responsible for antiinflammatory activity. Parentral steroids are useful in the preoperative period and during bronchospasm in asthmatic patients. Hydrocortisone $\mathrm{l}-2 \mathrm{mg} \cdot \mathrm{kg}^{-1}$ is recommended one to two hours preoperatively and three to four such doses are required during an asthmatic attack. Methylprednisolone has a similar duration of action, but has no mineralocorticoid activity and it does not affect salt and water balance. While long-term therapy produces some toxicity, short-term therapy has no side effects. An NIH expert panel on asthma recommended 
that patients with $\mathrm{FEV}_{1}$ of $<80 \%$ of predicted value should have oral steroids preoperatively. ${ }^{27}$

\section{CROMOLYN AND NEDOCROMIL}

These drugs, that prevent the release of vasoactive mediators from mast cells and other inflammatory cells, are effective in patients with atopy, and are free from side effects or drug interactions. The recommended dose is $2 \mathrm{mg}$ as an aerosol or $20 \mathrm{mg}$ of powder four times a day. In an acute asthmatic attack they have only a limited role. Nedocromil is more potent and is currently in use in Europe. The recommended dose is $4 \mathrm{mg}$ of powder 2 to 4 times per day.

\section{Bronchodilators}

\section{SYMPATHOMIMETICS}

Beta $_{2}$ adrenoceptor agonists are potent relaxants of the smooth muscle of the trachea and bronchi. Selective $B_{2}$ agonists such as albuterol, terbutaline, and fenotrol are the drugs of choice since they avoid the tachyarrhthmias associated with mixed $B_{1}$ and $B_{2}$ agonists like isoproterenol Adrenergic receptors are tonically activated in asthmatics and $B_{2}$ adrenoceptor agonists relax the airway smooth muscles and also inhibit the mediator release from the mast cells. ${ }^{28}$ There is also a reversal of oedema fluids, increased surfactant release, and mucociliary activity. Despite development of newer Bselective drugs, salbutamol remains the drug of choice. Salmeterol has a substituted analogue of salbutamol which binds with high affinity to an exo-site adjacent to the $B$ receptor on the cell membrane. This attachment permits the active head of the molecule to interact continuously with the receptor and allows the action of salmeterol to be maintained. Adrenergic agents are the treatment of choice for acute bronchoconstriction. Tremors, palpitations, and tachycardia are the most common side effects.

\section{XANTHINE DERIVATIVES}

This group of drugs produces bronchodilatation by inhibition of phosphodiestrase which, in turn, increases cAMP levels. They reduce inflammation and plasma exudation by selectively decreasing mast cell, eosinophil, platelet, and macrophage activity. They also produce smooth muscle relaxation by adenosine antagonism. The clearance is decreased in infants and the elderly. These drugs have a narrow margin of safety with serum therapeutic range of $10-20 \mu \mathrm{g} \cdot \mathrm{ml}^{-1}$. A loading dose of $5.6 \mathrm{mg} \cdot \mathrm{kg}^{-1}$ followed by an infusion of $0.5-0.9$ $\mathrm{mg} \cdot \mathrm{kg}^{-1} \cdot \mathrm{hr}^{-1}$ to maintain therapeutic levels is recommended. The metabolism of these drugs is decreased among smokers and those with liver disease. When used in combination with cimetidine, erythromycin, and oral contraceptives, toxic levels can be easily reached. Higher dosage is required when used with phenobarbital, phenytoin, and furosemide. Inhalation anaesthetic agents like halothane enhance arrhythmogenicity by sensitizing the myocardium, and their role in the prevention or treatment of bronchospasm has become controversial.

\section{Anticholinergics}

Cholinergic mechanisms play a major role in mediating reflex bronchoconstriction and, although less effective than $B$ agonists, these drugs can reduce bronchoconstrictive responses. In order to reach therapeutic levels without systemic side effects these drugs should be given as an aerosol or in a nebulized form. Glycopyrrolate and ipratropium bromide are quarternary ammonium agents and are almost free from central side effects unlike their tertiary ammonium counterpart, atropine which readily crosses the blood brain barrier. All these compounds are non selective and block prejunctional $M_{2}$ and post junctional $\mathrm{M}_{3}$ cholinergic receptors. An inhibition of the $M_{2}$ receptors can produce paradoxical bronchoconstriction.

\section{Miscellaneous drugs}

Immunotherapy is a more recent development in the treatment of asthma, and may be of particular benefit in an asthmatic surgical patient ${ }^{29}$ Methotrexate is useful in steroid-dependent asthmatics with secondary adverse effects from steroid therapy. ${ }^{30}$

\section{Upper respiratory tract infections}

Airway reactivity is considerably increased during upper respiratory tract infections (URI). This hyper-reactivity is neurally mediated and reflex vagal bronchoconstriction is enhanced. As a result of infection, bronchial epithelial surfaces are damaged and there is increased response to tachykinins. ${ }^{31}$ This reactivity can be attenuated by atropine suggesting that vagal respose is important in the pathogenesis of bronchospasm. Damage to the inhibitory muscarinic receptors (M2) by viral infection has been suggested as a possible mechanism of increased release of acetylcholine and subsequent bronchospasm. ${ }^{32}$ Children with URI are two to seven times more likely to have adverse events in the perioperative period, ${ }^{33}$ and there is an increased risk of post-operative desaturation in these patients. ${ }^{34}$ The risk of bronchospasm is much higher with endotracheal intubation.

There is a definitive risk of morbidity and mortality from airway reactivity and bronchospasm in asthmatic patients. ${ }^{35}$ Therefore, an understanding of the pathogenesis of the disease, risk factors associated with initiation of 
bronchospasm, therapeutic efficacy of different drugs, and an appropriate selection of the anesthetic technique, should help prevent perioperative complications.

\section{References}

1 Aquilina AT, Hall WJ, Douglas RJ, Utell MJ. Airway reactivity in subjects with viral upper respiratory tract infections: the effects of exercise and cold air. Am Rev Resp Dis 1980; 122: 3-10.

2 Cheney FW, Posner $K L$, Caplan $R A$. Adverse respiratory events infrequently leading to malpractice suits. Anesthesiology 1991; 75: 932-9.

3 Pinto Pereira LM, Orrett FA, Balbirsingh $M$. Physiological perspectives of therapy in bronchial hyper-reactivity. Can J Anaesth 1996; 43: 700-13.

4 Centers for Disease Control. Asthma-United States, 1982-1992. MMWR 1995; 43: 952-5.

5 Hogg RS, Schechter MT, Montaner JSG, Hogg JC. Asthma mortality in Canada, 1946 to 1990 . Can Respir J 1995; 2: 61-6.

6 Barnes PJ. Control of airway caliber. In: Fishman AP (Ed.). Update: Pulmonary Diseases and Disorders. New York: McGraw-Hill Inc., 1992.

7 Hashimoto $T$, Hirata $M$, Ito $\Upsilon$. A role for inositol 1,4,5-triphosphate in the initiation of agonist induced contractions of dog tracheal smooth muscle. $\mathrm{Br} \mathrm{J}$ Pharmacol 1985; 86: 191-9.

8 Krishnaswamy $G$, Liu $M C$, Su $S-N$, et al. Analysis of cytokine transcripts in the bronchoalveolar lavage cells of patients with asthma. Am J Respir Cell Mol Biol 1993; 9: 279-86

9 Sezikawa K, Sasaki H, Kubo T, Shimizu Y, Akaizawa $\Upsilon$, Takishima $T$. Effect of bronchomotor tone on work rate of breathing. J Appl Physiol 1984; 57: 7-13.

10 Takizawa T, Thurlbeck WM. Muscle and mucous gland size in the major bronchi of patients with chronic bronchitis, asthma, and asthmatic bronchitis. Am Rev Respir Dis 1971; 104: 331-6.

11 Empey $D W$, Laitinen $L A$, Jacobs $L$, Gold WM, Nadel $J A$. Mechanisms of bronchial hyperactivity in normal subjects after upper respiratory tract infection. Am Rev Respir Dis 1976; 113: 131-9.

12 Nadel JA. Autonomic control of airway smooth muscle and airway secretions. Am Rev Respir Dis 1977; 115: 117-26.

13 VanHoutte PM. Epithelium-derived relaxing factor(s) and bronchial reactivity. Am Rev Respir Dis 1988; 138: S24-30.

14 Widdicombe JG. Regulation of tracheobronchial smooth muscle. Physiol Rev 1963; 43: 1-37.

15 Hammouda $M$, Wilson WH. Reflex slowing of respiration accompanying the changes in intrapulmonary pressure. J Physiol (Lond) 1937; 88: 284-9.
16 Barnes PJ. Muscarinic receptor subtypes: implications for lung disease (Editorial). Thorax 1989; 44: 161-7.

17 Barnes PJ, Baraniuk JN, Belvisi MG. Neuropeptides in respiratory tract. Part 1. Am Rev Respir Dis 1991; 144: 1187-98.

18 Mortagy $A K$, Howell JBL, Waters WE. Respiratory symptoms and bronchial reactivity: identification of a syndrome and its relation to asthma. BMJ 1986; 293: 525-9.

19 Hetzel MR, Clark TJH. Comparison of normal and asthmatic circadian rhythms in peak expiratory flow rate. Thorax 1980; 35: 732-8.

20 Ramsdale EH, Morris MM, Roberts RS, Hargreave FE. Asymptomatic bronchial hyperresponsiveness in thinitis. J Allergy Clin Immunol 1985; 75: 573-7.

21 Kingston $H G G$, Hirshman CA. Perioperative management of the patient with asthma. Anesth Analg 1984; 63: 844-55.

22 Schnider SM, Papper EM. Anesthesia for the asthmatic patient. Anesthesiology 1961; 22: 886-92.

23 Lenox WC, Mitzner W, Hirshman CA. Mechanism of thiopental-induced constriction of guinea pig trachea. Anesthesiology 1990; 72: 921-5.

24 Hirsbman CA, Edelstein G, Peetz $S$, Wayne $R$, Downes $H$. Mechanism of action of inhalation anesthesia on airways. Anesthesiology 1982; 56: 107-11.

25 Swift $D L$. Aerosols and humidity therapy. Generation and respiratory deposition of therapeutic aerosols. Am Rev Respir Dis 1980; 122 (Suppl): 71-7.

26 Kern JA, Lamb RJ, Reed JC, Daniele RP, Nowell PC. Dexamethasone inhibition of interleukin 1 beta production by human monocytes. Posttranscriptional mechanisms. J Clin Invest 1988; 81: 237-44.

27 Sheffer $L A$. Expert panel on the management of asthma. J Allergy Clin Immunol 1991; 88: 425-534.

28 Church $M K$, Hiroi J. Inhibition of IgE-dependent histamine release from human dispersed lung mast cells by anti-allergic drugs and salbutamol. Br J Pharmacol 1987; 90: 421-9.

29 Barnes PJ. A new approach to the treatment of asthma. N Engl J Med 1989; 321: 1517-27.

30 Mullarkey MF, Webb DR, Pardee NE. Methotrexate in the treatment of steroid-dependent asthma. Ann Allergy 1986; 56: 347-50.

31 Dusser DJ, Jacoby DB, Djokic TD, Rubenstein I, Borson $D B$, Nadel JA. Virus induces airway hyperresponsiveness to tachykinins: role of neural endopeptidase. J Appl Physiol 1989; 67: 1504-11.

32 Fryer $A D$, Maclagan J. Muscarinic inhibitory receptors in pulmonary parasympathetic nerves in the guinea-pig. Br J Pharmacol 1984; 83: 973-8.

33 Coben $M M$, Cameron $C B$. Should you cancel the operation when a child has an upper respiratory tract infection? Anesth Analg 1991: 72: 282-8. 
34 DeSoto H, Patel RI, Soliman IE, Hannallah RS.

Changes in oxygen saturation following general anesthesia in children with upper respiratory infection signs and symptoms undergoing otolaryngological procedures. Anesthesiology 1988; 68: 276-9.

35 Bishop MJ, Cheney FW. Anesthesia for patients with asthma. Low risk but not no risk (Editorial). Anesthesiology 1996; 85: 455-6. 


\section{Hyperexcitabilité des voies aériennes et anesthésie}

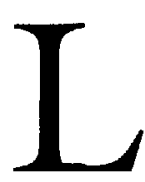

'HYPEREXCITABILITÉ des voies aériennes est souvent considérée comme synonyme d'asthme. Pourtant, la réactivité des voies aériennes s'accentue également chez ceux qui souffrent de rhinite allergique, de bronchite, d'emphysème et d'infections respiratoires virales. Chez ces patients, les voies aériennes se contractent de façon exagérée en présence de différents stimuli physiques, chimiques et environnementaux. Alors que chez l'asthmatique, l'hyperexcitabilité est chronique, chez ceux qui sont atteints d'une infection des voies respiratoires supérieures (IVRS), elle est aiguë et peut se prolonger au-delà de six semaines après la guérison de l'infection initiale. ${ }^{1}$ Comme ils sont sujets au bronchospasme périopératoire, ces patients inquiètent les anesthésistes au plus haut point, même les plus chevronnés. Le comité d'étude des réclamations réglées de l'ASA (Close Claims Study) mentionne que deux pour cent de toutes les réclamation d'origine respiratoire étaient en relation avec le bronchospasme et que $70 \%$ de celles-ci portaient sur des décès subséquents. ${ }^{2}$ Il est donc important de connaître l'épidémiologie, l'étiologie, la pathogénèse et le traitement des maladies causées par l'hyperexcitabilité des voies aériennes.

\section{L'asthme}

Même si la médecine n'a jamais cessé de progresser il n'en demeure pas moins que, dans les pays développés, l'asthme frappe encore $5 \%$ des adultes et $20 \%$ des enfants. ${ }^{3}$ La prévalence et la mortalité dues à l'asthme a augmenté constamment aux Etats-Unis et dans les autres parties du monde. ${ }^{3}$ Chez environ $66 \%$ de ces malades, les symtômes apparaissent avant l'âge de cinq ans et touchent plus souvent les sujets du genre masculin que ceux du genre féminin dans une proportion de 2 pour 1. Une analyse réalisée par le Centre for Disease Control (CDC) sur les données cliniques relatives à l'asthme de 1982 à 1991 a révélé une hausse du taux de la mortalité de $40 \%$. Cette hausse était de $50 \%$ chez les femmes et de $34 \%$ pour les hommes. ${ }^{4} \mathrm{Au}$ Canada, 87400 asthmatiques sont admis chaque année dans les hôpitaux et de 400 à 500 de ceux-ci décèdent. ${ }^{5}$
Girish C. Moudgil MBBS MSC FRCA FRCP
Physiopathologie de l'asthme

Dans la passé, les théories physiopathologiques de l'asthme se sont surtout intéressées au muscle bronchique lisse et à l'obstruction réversible du courant aérien causé par la bronchoconstriction. Tout en reconnaissant l'importance de ces facteurs, on est maintenant convaincu que l'inflammation conduits aériens est d'une importance capitale dans la pathogénèse de l'asthme. L'inflammation se manifeste spécifiquement par la prépondérence des éosinophiles, l'augmentation légère des neutrophiles et l'apparition précoce de la fibrose. ${ }^{6}$ L'atopie est évidente chez les deux tiers des malades, mais elle ne constitue pas un élément essentiel de la maladie. Cliniquement, la distinction entre l'asthme intrinsèque et l'asthme extrinsèque ne présente que peu d'intérêt. Chez tous les asthmatiques, on retrouve une interdépendance entre cellules inflammatoires, cytokines, médiateurs chimiques, muscles lisses, conduction neurogène, épithélium bronchique, vaisseaux et augmentation des sécrétions.

\section{Le tonus des muscles lisses des voies aériennnes}

Dans l'asthme, le rétrécissement des voies aériennes résulte des effets combinés de l'inflammation, de l'oedème et de la contraction des muscles lisses. La bronchoconstriction est provoquée par la stimulation par l'histamine, l'acétylcholine et les allergènes, des récepteurs situés sur la membrane cellulaire du muscle lisse. La stimulation des récepteurs active l'hydrolyse de la phosphoinositide, libérant ainsi dans la cellule des ions calcium qui entraînent la contraction des muscles lisses. L'hydrolyse de la phosphoinositide de la membrane constitue un élément essentiel à la libération du calcium intracellulaire une fois les récepteurs de surface activés. Lorsque le calcium intracellulaire augmente, il se lie à la calmoduline pour activer la chaîne légère de la myosine kinase (MLCK) qui en effectue la phosphorylation. Le couplage excitationcontraction des muscles lisses des voies aériennes est dépendant de la concentration cellulaire myoplasmique des ions calcium libres. ${ }^{7}$ L'augmentation de la tension musculaire est déterminées par l'ampleur de la phosphorylation de la MLCK. 


\section{Les cellules inflammatoires et les médiateurs}

Il est solidement établi que les cellules inflammatoires, les médiateurs et les cytokines jouent un rôle important dans la pathogénèse de l'asthme. Au point de vue cellulaire et moléculaire, on fait la distinction entre la réponse précoce et la réponse tardive. Dans la réponse précoce, les mastocytes interviennent comme médiateurs alors que la réponse tardive est caractérisée par l'intervention des éosinophiles, des lymphocytes, des neutrophiles et des macrophages alvéolaires. Dans la réponse précoce, la stimulation des récepteurs mastocytaires $\operatorname{IgE}$ par les antigènes libére des médiateurs comme l'histamine, la tryptase, l'héparine et les facteurs chémotactiques. De plus, les médiateurs dérivés de la membrane phospholipidique, la protaglandine D2, la leucotriène B4 et les cystéinyl-leucotriennes sont libérés et le bronchospame se produit en quelques minutes. La réponse tardive se manifeste de 6 à 12 heures après l'agression antigénique. L'activation éosinophilique et lymphocytaire est déclenchée par les leucotriènes, le facteur activateur des plaquettes (PAF), les interleukines IL2 et IL5 et le facteur stimulateur de la colonie granulocyte-macrophage (GM-CSF). On retrouve aussi chez les asthmatiques des concentrations élevées du messager RNA des cytokines IL2, IL3, ILA, IL5 et GM-CSF. ${ }^{8}$ Tous ces médiateurs contribuent à la bronchoconstriction, à l'augmentation de la perméabilité vasculaire, des sécrétions muqueuses et de la chémotaxie cellulaire.

\section{Mécanisme de l'byperexcitabilité des voies aériennes}

Plusieurs stimuli peuvent altérer le tonus bronchomoteur. L'exercice, les polluants, les irritants, les allergènes, le mouvement et l'air froid peuvent tous précipiter un bronchospasme. Chez l'humain, la contraction tonique est sous contrôle parasympathique vagal et se maintient normalement dans toutes les conduits aériens. Le tonus bronchomoteur de repos est responsable de l'équilibre entre l'espace mort anatomique et la résistance des voies aériennes. ${ }^{9}$ Les asthmatiques développent une hypertrophie et une hyperplasie des muscles lisses de l'arbre trachéobronchique avec intensification de leur excitabilité. ${ }^{10}$ Les infections virales rendent aussi les voies aériennes hyperexcitables et peuvent endommager sérieusement la barrière épithéliale et ainsi exposer les récepteurs sous-épithéliaux à des stimuli nocifs. ${ }^{11,12}$ La perte d'épithélium peut en outre entraîner une diminution de la production des facteurs de la relaxation dérivés de l'épithélium (EDRF) et des neuropepsidases qui ont pour fonction de détruire les facteurs qui déclenchent la constriction. ${ }^{13}$
Le système berveux autonome et le tonus broncbomoteur L'augmentation de l'activité parasympathique et la diminution de l'activité sympathique sont responsables de l'amplification du tonus et de la réactivité des voies aériennes. ${ }^{14}$ Le système nerveux parasympathique influence principalement le tonus bronchomoteur. Par contre, l'innnervation pulmonaire sympathique directe est plutôt limitée. Le sympathique exerce son action sur le tonus bronchomoteur principalement par la médiation des catécholamines circulantes sur les récepteurs $\mathrm{Bl}$; la bronchodilatation est produite par l'augmentation de l'AMP cyclique des muscles lisses. Différents récepteurs sensoriels modifient le tonus bronchomoteur en empruntant les voies afférentes de la conduction parasympathique. Situés profondément dans les muscles lisses de la paroi trachéale postérieure, des barorécepteurs à adaptation lente règlent la fréquence et la profondeur de la respiration et tout en contrôlant le réflexe d'insufflation d'Herring-Breuer. ${ }^{15}$ Des récepteurs à adaptation rapide sont présent dans la muqueuse des voies respiratoires et réagissent aux stimuli mécaniques, thermiques, et aux particules et gaz irritants. Des récepteurs juxtapulmonaires ou récepteurs «J» sont situés entre les alvéoles adjacentes aux capilaires pulmonaires et répondent aux altérations causées par la congestion pulmonaire, l'oedème, l'inflammation et l'exercice. Les voies de conduction efférentes parasympathiques suivent le nerf vague pour former des synapses ganglionnaires dans les parois des conduits aériens. Cette activation est modulée par des récepteurs muscariniques (M) présents dans les mêmes ganglions autonomes. Des fibres postganglionnaires courtes pénètrent dans les muscles lisses et les glandes sous-muqueuses des voies respiratoires. La stimulation des récepteurs postjonctionnels muscariniques M3 par l'acétylcholine produit la contraction des muscles lisses. Les récepteurs muscariniques M2 sont inhibiteurs et limitent le degré de la bronchoconstriction cholinergique en produisant un feedback négatif sur la libération de l'acétylcholine. ${ }^{16}$

\section{La co-transmission cholinergique}

On a aussi décrit une voie accessoire neurale «non adrénergique - non cholinergique»(NANC). ${ }^{17}$ Cette voie affecte toute la trachée et les bronches les plus petites. Il s'agit d'un système inhibiteur bronchodilatateur avec une composante excitatrice bronchoconstristrice. Le rôle de cette voie n'est pas encore nettement défini.

\section{Classification de l'asthme}

L'asthme n'est pas un maladie unique mais elle comprend un groupe d'affections comportant des mécanismes pathologiques variés. La principale classification de l'asthme bronchique est la suivante: 
1. L'asthme atopique ou à médiation par l'immunoglobuline $\mathrm{E}$

2. L'asthme provoqué par l'exercice,

3. L'asthme professionnel,

4. L'asthme infectieux,

5. L'asthme induit par l'aspirine.

L'asthme bronchique à médiation par l'immunoglobuline $\mathrm{E}$ constitue la forme la plus commune et serait héréditaire. L'inhalation d'une substance antigénique provoque la formation de l'anticorps IgE. Au moment d'une nouvelle exposition aux mêmes antigènes, un complexe antigène-anticorps se développe sur les récepteurs de surface des mastocytes. Le changement de configuration de la membrane cellulaire qui en résulte libère des médiateurs vasoactifs dont l'histamine qui provoquent la constriction des muscles lisses.

Indépendamment de la classification, quel que soit le type d'asthme, les mêmes médiateurs vasoactifs sont libérés et ont les mêmes effets: la bronchoconstriction et l'obstruction du flux aérien.

\section{Évaluation préopératoire}

Une histoire de crises de dyspnée et de wheezing devrait mettre l'anesthésiste sur la piste d'une maladie bronchospastique. Pour être capable de prévenir le bronchospasme à la période périopératoire, une histoire et une évaluation complètes s'imposent. (Tableau I).

TABLEAU I Points à préciser au moment de l'évaluation préopératoire

\begin{tabular}{|c|c|}
\hline L'bistoire & Précisions \\
\hline Le patient & $\begin{array}{l}\text { L'âge au début de la maladie } \\
\text { Les allergies } \\
\text { Les facteurs sociaux et psychologiques }\end{array}$ \\
\hline La maladie & $\begin{array}{l}\text { L'évolution cyclique } \\
\text { Les facteurs précipitants } \\
\text { Les effets sur le sommeil } \\
\text { Les manifestations: la toux, les sécrétions } \\
\text { et leurs caractéristiques }\end{array}$ \\
\hline Le traitement médical & $\begin{array}{l}\text { La médication } \\
\text { Le nombre d'hospitalisation } \\
\text { Les anesthésies antérieures }\end{array}$ \\
\hline
\end{tabular}

La dyspnée nocturne et l'oppression thoracique sont des signes d'hyperexcitabilité bronchique. ${ }^{18}$ Ces symptômes et l'habitude du tabagisme doivent toujours nous inciter à rechercher la bronchoconstriction, sa gravité et sa réversibilité. Après un traitement avec un bronchodilatateur, l'augmentation du VEMS doit dépasser $15 \%$ pour que la bronchoconstriction soit considérée comme vraiment réversible. Le débit expiratoire de pointe (DEP) est facile à mesurer de façon répétée. De petites variations diurnes du DEP surviennent chez les individus en bonne santé ; ces variations sont toutefois exagérées dans l'asthme ${ }^{19}$ et la rhinite allergique. ${ }^{20}$ Alors que la toux et la dyspnée peuvent nous mettre sur la piste d'une maladie respiratoire, l'épreuve de provocation à la méthacholine confime l'hyperexcitabilité des voies aériennes.

Sur la base de l'histoire et des données cliniques, Kingston et Hirschman ${ }^{21}$ ont proposé de classifier le patient asthmatique en trois groupes (Tableau II). Cette classification clinique tient compte de la gravité de la maladie et est considérée comme pronostique des complications et de la morbidité périopératoires. Les épreuves fonctionnelles pulmonaires compléteront l'évaluation de la maladie sous l'aspect de sa gravité (Tableau III). En plus des épreuves fonctionnelles, les examens paracliniques suivants sont suggérés:

\section{La gazométrie}

Elle est rarement indiquée pour l'évaluation préopératoire de l'asthmatique. L'hypercarbie et l'hypoxémie prouvent la gravité de la maladie.

TABLEAU III Classification clinique de la détérioration de la fonction pulmonaire dans l'asthme

\begin{tabular}{lll}
\hline & CV, CVF, VEMS, MVV & FEF 25-75\% \\
\hline Normale & $>80 \%$ & $>75 \%$ \\
Légère & $65-80 \%$ & $60-75$ \\
Modérée & $50-64 \%$ & $45-59 \%$ \\
Grave & $35-49 \%$ & $33-44 \%$ \\
Très grave & $<35 \%$ & $<30 \%$ \\
\hline
\end{tabular}

TABLEAU II

\begin{tabular}{cll}
\hline Groupe & Histoire & Action conseillée \\
\hline I & $\begin{array}{l}\text { Histoire de wheezing } \\
\text { Absence de wheezing pendant plusieurs années } \\
\text { Aucun médicament contre l'asthme } \\
\text { Pas de wheezing présentement }\end{array}$ & $\begin{array}{l}\text { Examen physique habituel } \\
\text { Spirométrie souhaitable }\end{array}$ \\
II & $\begin{array}{l}\text { Histoire de bronchospasme récurrent } \\
\text { Pésentement sous thérapie aux bronchodilatateurs } \\
\text { Wheezing préopératoire }\end{array}$ & $\begin{array}{l}\text { Bronchodilatateurs en prévention recommandés } \\
\text { Gazométrie souhaitable } \\
\text { Trétement préventif aux bronchodilatateurs recommandé }\end{array}$ \\
& Pésentement sous thérapie aux bronchodilatateurs & $\begin{array}{l}\text { Spirométrie préopératoire nécessaire } \\
\text { Gazométrie nécessaire }\end{array}$ \\
& & Thérapie intensive aux bronchodilatateurs
\end{tabular}




\section{La radiographie des poumons}

La radiographic pulmonaire systématique n'a ordinairement que peu de valeur et ne peut être utile que pour éliminer les complications comme la pneumonie et l'insuffisance cardiaque.

\section{L'électrocardiographie}

Les asthmatiques sont sujets au bloc de branche droit, à l'ectopie ventriculaire et à l' hypertrophie auriculaire gauche aiguë pendant la crise. Comme l'hypoxie au cours d'une crise peut évoluer vers des anomalies cardiaques sérieuses, on utilisera l'ECG initial comme point de comparaison.

\section{L'approche anesthésique}

L'anesthésie régionale a beaucoup à offrir au patient asthmatique et demeure la technique de choix. Losqu'elle est impossible et que l'anesthésie générale devient nécessaire, il faut éviter les agents susceptibles de déclencher la libération de l'histamine et autres substances vasoactives. L'intubation est à éviter lorsque c'est possible

\section{La prémédication}

Parce qu'ils provoquent une libération d'histamine et de la dépression respiratoire, les morphiniques devraient être écartés. Les antagonistes des récepteurs $\mathrm{H}_{1}$ par leurs propriétés sédatives et assèchantes sont des médicament d'appoint utiles, alors que les antagonistes des récepteurs $\mathrm{H}_{2}$ lorsqu'ils sont administrés seuls peuvent être nocifs parce qu'il bloquent le contrôle de feedback inhibiteur dû à la libération du médiateur. Les benzodiazépines sont un excellent choix.

\section{Les agents d'induction}

Bien qu'à doses cliniques le thiopentone ne protège pas du bronchospasme réflexe, il ne constitue pas une contreindication dans l'asthme. L'incidence plus élevée de bronchospasme est due à la présence d'un tube endotrachéal sous anesthésie légère, et non au thiopentone per se. ${ }^{22} \grave{A}$ des concentrations cliniques, le thiopentone produit une bronchoconstriction proportionnelle à la dose; par contre, une augmentation légère de celle-ci produit de la bronchodilatation. ${ }^{23}$ Chez l'asthmatique, l'induction à la kétamine a des effets bénéfiques sur le tonus bronchomoteur en produisant une relaxation musculaire lisse à la fois directe et indirecte, secondairement à la libération de catécholamines. L'étomidate ne libère pas d'histamine ni ne déclenche de bronchospasme. À l'induction chez l'asthmatique, le propofol est aussi un agent sûr et est moins susceptible d'induire un bronchospasme que le thiopentone.

\section{L'anesthésie par inhalation}

L'halothane, l'enflurane et l'isoflurane préviennent et même abolissent la bronchoconstriction. ${ }^{24}$ Le sévoflu- rane peut aussi être utilisé chez l'asthmatique. Par contre, le desfluarene peut causer de la bronchoconstriction par son acreté et l'irritation trachéale qu'il produit. L'aminophylline à concentration toxique à une plus forte tendance à causer des arythmies ventriculaires en présence d'halothane que d'enflurane, d'isoflurane, de sévoflurane et de desflurane. La morphine est associée à des augmentations de la concentration plasmatique d'histamine et devrait être évitée.

\section{Les myorelaxants}

Les curarisants comme la d-tubocurarine et l'atracurium libèrent de l'histamine et devraient être évités. La décurarisation à la néostigmine peut précipiter un bronchospasme par la stimulation des récepteurs muscariniques qui peut être prévenue par l'administration de doses judicieuses d'atropine. Le pancuronium, le vécuronium et le rocuronium ne libèrent pas d'histamine et peuvent donc être administrés sans danger aux asthmatiques.

\section{Les anesthésiques locaux}

L'administration de $1,5 \mathrm{mg} \cdot \mathrm{kg}^{-1}$ de lidocaïne prévient le bronchospasme réflexe et il est recommandé de l'administrer avant toute manipulation des voies aériennes, tant à l'intubation qu'à l'extubation. La procaïne et la bupivacaïne ne présentent aucun avantage sur la lidocaïne.

\section{Les médicaments spécifiques contre l'asthme}

Deux groupes majeurs de médicaments sont présentement à notre disposition pour vaincre le bronchospasme chez les asthmatiques; les bronchodilatateurs pour abolir ou prévenir le bronchospsme et les anti-inflammatoires pour contrôler une réponse inflammatoire indésirable. L'administration en aérosols est particulièrement avantageuse parce que le produit est délivré au site actif de l'arbre trachéobronchique. ${ }^{25}$ Les médicaments majeurs (dont les xanthines, les sympathicomimétiques et les stéroïdes) constituent le traitement de base du bronchospasme et on les administre à la période préopératoire pour le contrôle de l'asthme. Les produits mineurs (mucolytiques, les inhibiteurs des récepteurs histaminiques, les stabilisateurs des mastocytes, les parasymopathicolytiques et les inhibiteurs calciques) peuvent être efficaces pour prévenir le bronchospasme mais non pour traiter sa forme aiguë.

\section{Les anti-inflammatoires}

1. LES GLUCOCORTICOÏDES

Les glucocorticoïdes (CGS) sont actuellement les plus puissants anti-inflammatoires disponibles pour vaincre 
la bronchoconstriction symptomatique. En inhalation, des doses aussi faibles que $400 \mu \mathrm{g}$ de béclométhasone dipropionate (BPD) sont très efficaces. Le dipropionate de béclométhasone (DPB) et son métabolite le monopropionate sont des puissants GCS avec une affinité spéciale pour les récepteurs polmonaires. L'efficacité des GCS résulte de l'inhibition de la formation et de la libération de PAF, LTD4, LTB4, de l'histamine et de PGE2 et de la production des cytokines, dont $\mathrm{IL}-1, \mathrm{IL}$ 2. IL-6, TNF et GM CSF. ${ }^{26}$ Cette inhibition se situe au niveau de la transcription et de la translation des gênes. Les complexes récepteurs - CGS se lient au DNA, déclenchent la transcription de mRNA et induisent la synthèse de la lipocortine et de la vasocortine desquelles dépend l'efficacité anti-inflammatoire. Les stéroïdes administrés par la voie parentérale sont efficaces à la période préopératoire et pendant le bronchospasme. Il est recommandé d'administrer $1-2 \mathrm{mg} \cdot \mathrm{kg}^{-1}$ d'hydrocortisone une ou deux heures avant l'intervention et de trois à quatre fois cette dose pendant une crise d'asthme. Le méthylprednisolone a la même durée d'action, mais n'ayant pas d'activité minéralocorticoïde, n'agit pas sur l'équilibre hydroélectrolytique. Le traitement de longue durée a des effets toxiques, contrairement au traitement de courte durée. Un panel d'experts du NIH recommande d'administrer des stéroïdes oraux avant une intervention si le VEMS est inférieur à $80 \%$ de la valeur prédite. ${ }^{27}$

\section{LE CROMOLYN ET LE NÉDOCROMIL}

Ces médicaments préviennent la libération de l'histamine à partir des mastocytes et autres cellules inflammatoires. Ils sont efficaces contre l'atopie et n'ont pas d'effets secondaires ni d'interactions. La posologie recommandée est de $2 \mathrm{mg}$ en aérosol ou $20 \mathrm{mg}$ en poudre quatre fois par jour. Pendant une crise aiguë, leur efficacité est limitée. Le nédocromil, présentement utilisé en Europe, est plus puissant. La posologie recommandéée est de $4 \mathrm{mg}$ de la poudre de deux à quatre fois per jour.

\section{Les bronchodilatateurs}

\section{LES SYMPATHICOMIMÉTIQUES}

Les agonistes $B_{2}$-adrénergiques sont de puissants relaxants des muscles lisses de la trachée et des bronches. Parce que les agonistes sélectifs $B_{2}$ comme l'albutérol, la terbutaline et le fénotrol permettent d'éviter la tachycardie associée aux agonistes mixtes $B_{1}$ et $B_{2}$ comme l'isoprotérénol, il représentent les médicaments de choix. Chez les asthmatiques, le tonus des récepteurs adrénergiques est activé et les agonistes $\beta_{2}$-adrénergiques relaxent les muscles lisses des voies aériennes et inhibent la libération des médiateurs de l'histamine mastocy- taire. ${ }^{28}$ Le liquide d'oedème s'inverse, la libération de surfactant et l'activité ciliaire se rétablissent. Malgré l'apparition de nouveaux médicaments B-sélectifs, le salbutamol demeure le médicament de choix. Le salmétérol est un analogue du salbutamol qui se lie avec une forte affinité à un exo-site adjacent au récepteur $\beta$ de la membrane cellulaire. Cette liaison permet à la tête active de la molécule d'interagir continuellement avec le récepteur, ce qui donne au salmétérol une activité soutenue. Les agents adrénergiques constituent les médicaments de choix contre la bronchoconstriction aiguë. Les effets secondaires les plus fréquents sont les tremblements, les palpitations et la tachycardie.

\section{LES DÉRIVÉS DE LA XANTHINE}

Ce groupe de médicaments produit une bronchodilatation par l'inhibition des phosphodiestérases, qui, à leur tours, augmentent la concentration de la cAMP. Ils réduisent l'inflammation et l'exsudation plasmatique en diminuant sélectivement l'activité des mastocytes, des éosinophiles, des plaquettes et des macrophages. Ils relaxent aussi les muscles lisses par antagonisme de l'adénosine. Le clairance des xanthines est diminuée chez les enfants et les personnes âgées. La marge de sécurité de ces médicaments est étroite et la dose thérapeutique se situe entre 10 et $20 \mu \mathrm{g} \cdot \mathrm{ml}^{-1}$. Pour maintenir un niveau thérapeutique, il est recommandé d'administrer une dose initiale de $5,6 \mathrm{mg} \cdot \mathrm{kg}^{-1}$ suivie d'une perfusion de 0,5 à $0,9 \mathrm{mg} \cdot \mathrm{kg}^{-1} \cdot \mathrm{h}^{-1}$. Le métabolisme de ces dérivés est diminué chez les fumeurs et les hépatiques. Leur association à la cimétidine, l'érythromycine et les contraceptifs oraux peut facilement conduire à des niveaux toxiques. Ils faut augmenter les doses avec le phénobarbital, la phénytoine et le furosémide. L'halothane comme d'autres agents inhalatoires sensibilisent le myocarde et augmente ainsi l'incidence des arythmies. Leur rôle préventif sur le bronchospasme est toujours débattu.

\section{Les anticholinergiques}

Les mécanismes cholinergiques sont importants pour la médiation de la bronchoconstriction réflexe, et bien que moins efficaces que les agonistes $B$, les anticholinergiques peuvent atténuer les effets de la bronchoconstriction. Pour pouvoir atteindre un niveau thérapeutique libre d'effets secondaires systémiques, ces produits doivent être administrés en aérosols ou en nébulisation. Le glycopyrrolate et le bromure d'ipratropium sont des composés ammonium quaternaires et sont presque sans effets secondaires centraux contrairement à l'atropine, un ammonium tertiaire qui traverse facilement la barrière hématoencéphalique. Tous ces produits sont non sélectifs et bloquent les récepteurs cholinergiques 
préjonctionnels M2 et postjonctionnels M3. L'inhibition des récepteurs M2 peut provoquer une bronchoconstriction paradoxale.

\section{Autres traitementst}

L'immunothérapie cconstitue un ajout récent au traitement de l'asthme et peut être particulièrement avantageuse avant la chirurgie. ${ }^{29} \mathrm{Le}$ méthotrexate est utile chez les asthmatiques sujets aux effets secondaires des stéroïdes. ${ }^{30}$

\section{Les infections des voies respiratoires supérieures}

La réactivité des voies aériennes augmente considérablement pendant une IVRS. Cette réactivité est contrôlée par la médiation vagale qui exagère la bronchoconstriction réflexe. Le dommage causé à la surface épithéliale par l'infection accentue la réponse aux tachykinines. ${ }^{31}$ l'excitabilité est atténuée par l'atropine ce qui suggère l'importance de la réponse vagale dans la pathogénèse du bronchospasme. Il a été proposé que les lésions causées aux récepteurs muscariniques inhibiteurs (M2) par l'infection virale pourraient déclencher l'augmentation de la libération de l'acétylcholime et le bronchospasme subséquent. ${ }^{32}$ Les enfants atteints d'IVRS sont de deux à sept fois plus sujets à des incidents fâcheux à la période périopératoire ${ }^{33}$ avec un risque accru de désaturation postopératoire. ${ }^{34}$ L'intubation enddotrachéale augmente en elle-même le risque de bronchospasme.

Chez l'asthmatique, la réactivité et le bronchospasme augmentent de façon absolue le risque de morbidité et de mortalité. ${ }^{35}$ Il est donc important de comprendre la pathogénèse de la maladie, les facteurs associés au déclenchement du bronchospasme et la valeur des différents agents thérapeutiques. Le choix pertinent de la technique anesthésique devrait aider à prévenir les complications périopératoires.

\section{Références}

(Voir page $\mathbf{R} 82$ ) 